\title{
Experimental arthritis induced by atypical strains of Streptococcus pyogenes
}

\author{
B. D. BARRIDGE, M. BISHR, F. KAHN and J. L. ALLEN
}

\begin{abstract}
Department of Biology and Microbiology, Northwestern State University of Louisiana, Natchitoches, LA 71497, USA
\end{abstract}

\begin{abstract}
Summary. Experimental arthritis was induced in Sprague-Dawley rats by intraarticular injection of whole-cell sonicates, heat-killed cells and cell-wall preparations of typical and atypical strains of Group-A streptococci (Streptococcus pyogenes). The non-haemolytic nitrosoguanidine-derived mutant and the naturally occurring Lowry strain induced a similar but less severe form of arthritis. Direct immunofluorescent staining demonstrated maximum fluorescence in the sections of articular joint taken 60 days after injection. The level of immune complexes increased for up to 90 days after injection of cell walls or whole-cell sonicates and correlated well with the development of the chronic stage of arthritis observed in haematoxylin and eosin and fluorescence staining of thin tissue sections.
\end{abstract}

\section{Introduction}

Whole-cell sonicates of Group-A streptococci and streptococcal cell-wall components have been shown to induce experimental arthritis in rats (Schwabetal., 1967; Cromartie et al., 1977; Anderle et al., 1979; Clark et al., 1979; Wilder et al., 1983). Each of these studies used typical Group-A $\beta$ haemolytic streptococci as the arthritis-inducing agent. This paper describes the ability of atypical, non-haemolytic strains of Streptococcus pyogenes to induce experimental arthritis in Sprague-Dawley rats. Non-haemolytic strains are more difficult to identify and characterise in routine diagnostic laboratories and their ability to induce arthritis warrants concern about their pathogenicity for man.

\section{Materials and methods}

\section{Organisms}

S. pyogenes Lancefield SS-95 and the non-haemolytic Lowry strain were obtained from Dr R. Facklam, Center for Disease Control, Atlanta, Georgia. A non-haemolytic mutant of the parent SS-95 strain was isolated by treatment with $\mathrm{N}$-methyl- $\mathrm{N}^{\prime}$-nitro-nitrosoguanidine as described previously (Owens et al., 1978).

Received 23 Nov. 1987; revised version accepted 20 Feb. 1988.

\section{Cell preparations}

$S$. pyogenes strains were grown in Todd-Hewitt broth as previously described (Owens et al., 1978). Cells from $1.5 \mathrm{~L}$ of broth were harvested by centrifugation, resuspended and washed three times in sterile phosphatebuffered saline (PBS), pH 7.0. Washed, packed whole cells were resuspended in $30 \mathrm{ml}$ of PBS and ultrasonicated for 90 min (Sonifier Cell Disruptor, Model W185D from Heat Systems-Ultrasonics, Inc., Plainview, L.I., New York). Whole-cell sonic extracts and cell-wall suspensions were isolated and purified according to the procedure of Anderle et al. (1979) and the rhamnose content of the cell walls was determined by the method of Dische and Shettles (1948). Heat-killed whole cells were prepared by resuspending the washed, packed cells from $1 \mathrm{~L}$ of ToddHewitt broth in $15 \mathrm{ml}$ of PBS and heating at $80^{\circ} \mathrm{C}$ for $30 \mathrm{~min}$. All preparations were checked for sterility by plating on blood agar.

\section{Experimental animals}

Outbred male and female Sprague-Dawley rats weighing 150-250 g (Sasco, Inc., Omaha, NB) were divided into nine groups. Each group contained eight animals which were given injections of (1) whole-cell sonicates, (2) heat-killed whole cells, or (3) purified cell walls from the parent $\beta$-haemolytic $S$. pyogenes, the non-haemolytic mutant, or the Lowry strain. Doses for injection were calculated on the basis of the rhamnose content of the streptococcal cell wall (Cromartie et al., 1977; Greenblatt et al., 1980) and a single intra-articular injection was made with rhamnose concentrations in the range 3$100 \mu \mathrm{g} / \mathrm{g}$ body weight. These doses represented approximately $1-33.3 \mathrm{mg}$ of cell-wall material. Control animals 
received either an equal concentration of analytical grade rhamnose or an equal volume of PBS. Animals to be used for radiological or histological examination, for studies of immune complex formation, or immunofluorescence received a single intra-articular injection of whole-cell sonicate or cell-wall preparations of the parent or nonhaemolytic mutant equivalent to rhamnose $60 \mu \mathrm{g} / \mathrm{g}$ body weight (approximately $20 \mathrm{mg}$ of cell-wall material).

\section{Evaluation of arthritis}

Animals were monitored daily for the first 2 weeks and twice weekly thereafter until completion of the experiments. Joint diameter was measured with a steel caliper calibrated to read to $0.05 \mathrm{~mm}$. Severity was scored on a scale of $0-4$ based on inflammation, oedema of periarticular tissue, and enlargement, distortion or ankylosis of the joint (Cromartie et al., 1977; Hunter et al., 1980). Joint lesions were observed by X-ray and histological techniques.

\section{Radiological techniques}

Rats were anaesthetised by intra-peritoneal injection of ketamine hydrochloride $100 \mathrm{mg} / \mathrm{kg}$ body weight. Xrays were taken with a General Electric X-ray machine (MST62511) with a 200-ma focal spot. Exposures were made for $0.25 \mathrm{~s}$ at $32 \mathrm{kv}$ without a filter. The focal film distance was 40 in. with an object-film distance of 6 in. Kodak min- $\mathrm{R}$ cassetes with Kodak min- $\mathrm{R}$ screen and single coated Kodak min-R film were used. Each radiograph was evaluated for the presence and severity of soft-tissue swelling, joint effusion, joint narrowing, osteoporosis, bone erosion, and subperiosteal new bone formation.

\section{Histology}

Joint sections were taken from arthritic rats killed periodically after injection of whole-cell sonicates or cellwall preparations of the parent, mutant or Lowry strains. Samples were immersion-fixed in $10 \%$ neutral buffered formalin. Joint specimens were decalcified in formic acid and sodium citrate solutions for $10-15$ days after fixation. Paraffin embedded specimens were stained with haemotoxylin-eosin (H \& E) or with periodic acid schiff (PAS).

\section{Immunofluorescence}

Animals from control and test groups were killed after $0,3,15,30,60,90$ and 300 days. Ankle and knee joints were collected, fixed in $10 \%$ formalin and sections 10 $15 \mu \mathrm{m}$ thick were taken. Sections were stained with fluorescein isothiocyanate conjugated rat anti-IgG and anti-IgM antibodies according to routine procedures for direct immunofluorescence staining. Photographs were taken with a $35 \mathrm{~mm}$ camera (Leitz) attached to a fluorescent microscope (E. Leitz, Wetzlar).

\section{Immune complexes}

A slight modification of the polyethylene glycol precipitation method of Van der Giessen and The (1986) was used to detect immune complexes. Serum samples $(150 \mu \mathrm{l})$ from arthritic rats given whole-cell sonicates or cell walls of the parent or mutant strains, were mixed with $450 \mu \mathrm{l}$ of $0.08 \mathrm{M}$ calcium carbonate and $3 \mathrm{ml}$ polyethylene glycol (PEG) $5 \%$ in $0.1 \mathrm{M}$ borate buffer, $\mathrm{pH} 8.4$. The mixture was left at $4^{\circ} \mathrm{C}$ overnight and centrifuged for $3 \mathrm{~min}$ at $3500 \mathrm{~g}$. The supernate was carefully removed and the pellet dissolved in $3 \mathrm{ml}$ of $0.1 \mathrm{M}$ sodium chloride. Optical density at $280 \mathrm{~nm}$ was recorded.

\section{Chemicals and growth media}

Todd-Hewitt broth was from BBL, Cockeysville, MD, fluorescent labeled rat anti-IgM and anti-IgG were from Serotech, Indianapolis, IN, and ketamine hydrochloride was from Parke-Davis, Morris Plains, NJ. All other chemicals were from Sigma Chemicals, St Louis, MO.

\section{Results}

\section{Induction of experimental arthritis}

Comparison was made between the typical haemolytic Group-A streptococcus and the two atypical, non-haemolytic strains for their ability to induce experimental arthritis in rats. Development and severity of arthritis induced by the typical and atypical strains showed a dose-dependent response similar to that observed for other species of Streptococcus previously tested in this model (Cromartie et al., 1977; Hunter et al., 1980; Eisenberg et al., 1982; Esser et al., 1986). As little as the equivalent of rhamnose $3 \mu \mathrm{g} / \mathrm{g}$ body weight of the whole-cell sonicate or purified cell walls from the parent typical Group-A streptococcus induced the primary inflammatory response in 3 of 8 animals tested. All animals developed inflammation when given doses equivalent to $>20 \mu \mathrm{g}$ of rhamnose $/ \mathrm{g}$ body weight. Doses equivalent to $30 \mu \mathrm{g}$ of rhamnose/g body weight of the mutant or Lowry strains were necessary to induce arthritis. Swelling and erythema were observed in the ankle or knee joint, or both, beginning on day 2 and lasting 5-7 days in animals that had received either parent or mutant whole-cell sonicates or purified cell walls. Those animals receiving the Lowry strain required 4-5 days longer for the primary inflammatory response to appear and they failed to develop the chronic erosive stage with any concentrations. Heat-killed whole cells of the parent or mutant induced swelling and erythema but to a lesser extent than in animals treated with whole-cell sonicates or cell walls. 
Controls receiving PBS or analytical grade rhamnose did not exhibit inflammation or other symptoms of arthritis.

Soft-tissue swelling, calcification, bony overgrowth of the joint and joint narrowing could be seen (figs. 1 and 2) during the clinical and chronic stages of the disease.

\section{Histological observations}

Sections from the ankle or knee joint revealed the chronic erosive nature of the joint tissue when stained with $\mathrm{H} \& \mathrm{E}$ or PAS. This phase was characterised by hyperplasia of the synovial lining cells, destruction of the cartilage and subchondral bone and replacement of this tissue by fibrous connective tissue. Irregularly shaped islets of osteoid tissue were seen surrounding the area of bone destruction. In some areas, invasion of chrondroid and osteoid tissue by fibrous tissue (osteofibrosis), pannus formation and extension of fibrous connective tissue over the articular cartilage could be seen (figs. 3, 4 and 5). Proliferation of connective tissue of the stroma of synovial villi and infiltration of tissue by mononuclear phagocytes and lymphocytes were also observed. Eventually the joint space became filled with connective tissue and the destroyed articular cartilage was replaced by fibrous connective tissue leading to complete joint ankylosis and the loss of normal bone and cartilage architecture. The Lowry strain primarily induced swelling of the peri-articular tissue such as the ligaments, joint capsule and fibrous tissue around the joint.

\section{Fluorescent antibodies}

Ankle and knee joint sections from controls and animals given whole-cell sonicates or cell walls from either the parent or mutant strain were stained with fluorescein isothiocyanate-conjugated anti$\mathrm{IgG}$ and anti-IgM. With uninoculated control rats, there was no pre-existing $\operatorname{IgG}$ or $\operatorname{IgM}$ in the synovium. Sections from treated groups, stained 3 and 15 days after injection, also showed no fluorescence against anti-IgG or anti-IgM. Fluorescence with anti-IgG was first detected in joint tissues 30 days after injection and reached a peak within 60 days (fig. 6). Most of the fluorescence appeared in the articular cartilage 300 days after injection of the antigen. All fluorescence observed was in response to anti-IgG and fluorescence could not be detected at any stage of the disease when anti-IgM was added to the tissue. These data indicate the presence of IgG in the cells of the synovial membrane or on their surface and suggest the presence of immune complexes at these sites.

\section{Immune complexes}

The level of immune complexes increased up to 90 days after injection of whole-cell sonicates or cell

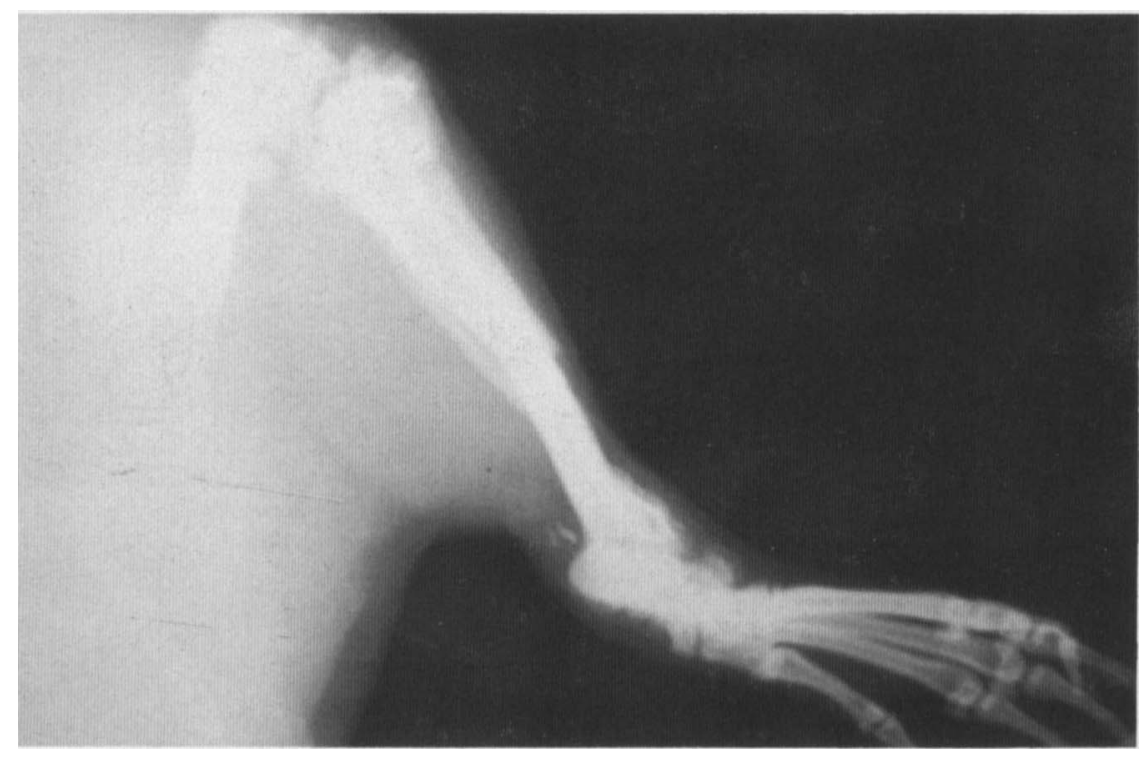

Fig. 1. Radiographs of knee and ankle joints 3 months after intra-articular injection of parent Streptococcus whole-cell sonicates (equivalent to rhamnose $60 \mu \mathrm{g} / \mathrm{g}$ body weight). Calcification, bony overgrowth and narrowing of the joint can be seen. Subperiosteal new bone formation is evident in distal extremities of the tibia and proximal tarsus. 

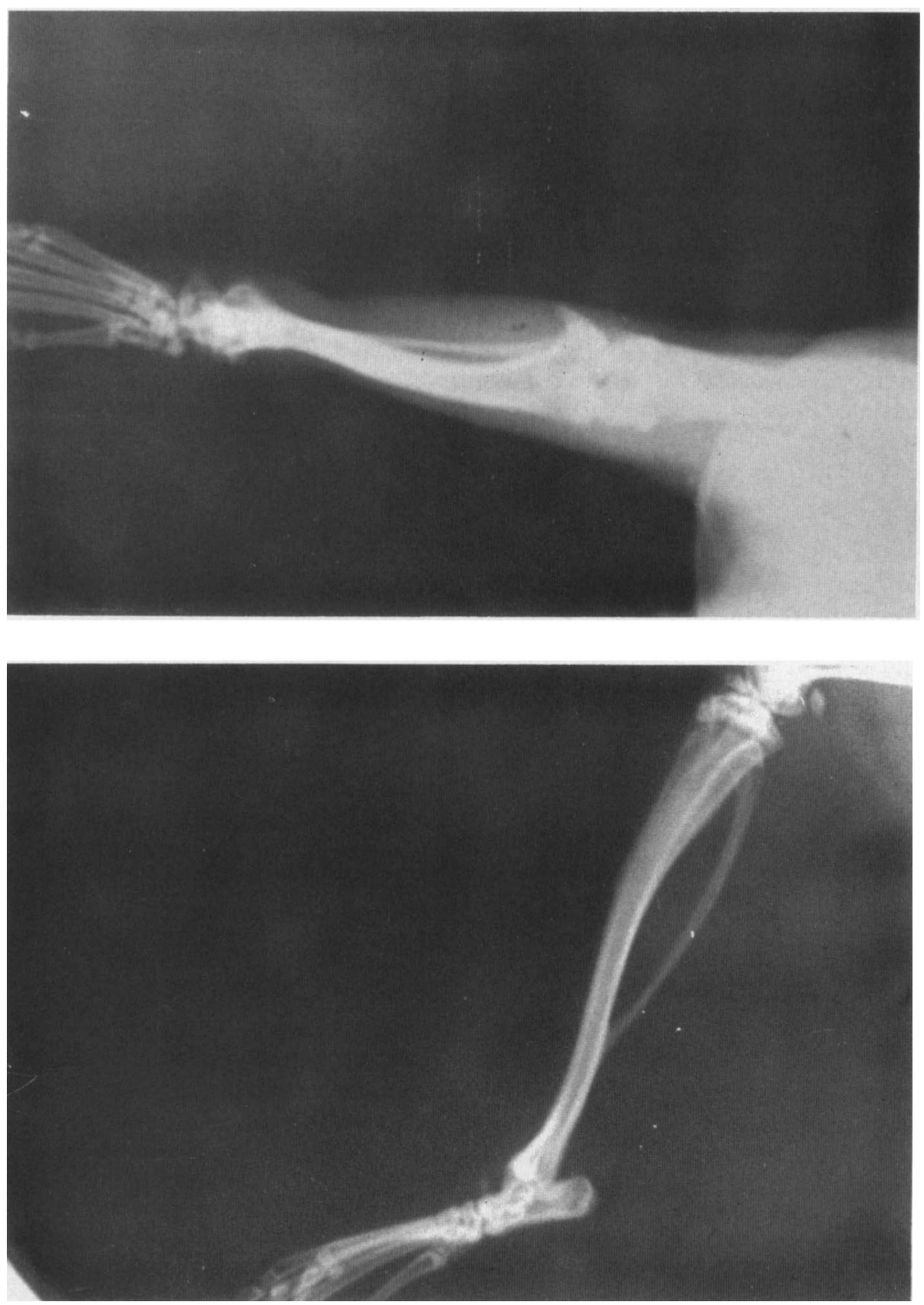

Fig. 2. X-ray from a rat 3 months after intra-articular injection of non-haemolytic mutant whole-cell sonicates (equivalent to rhamnose $60 \mu \mathrm{g} / \mathrm{g}$ body weight). Mild soft tissue swelling, calcification, and joint narrowing can be seen. Arthritis is less severe than in animals receiving the parent whole-cell sonicate. 


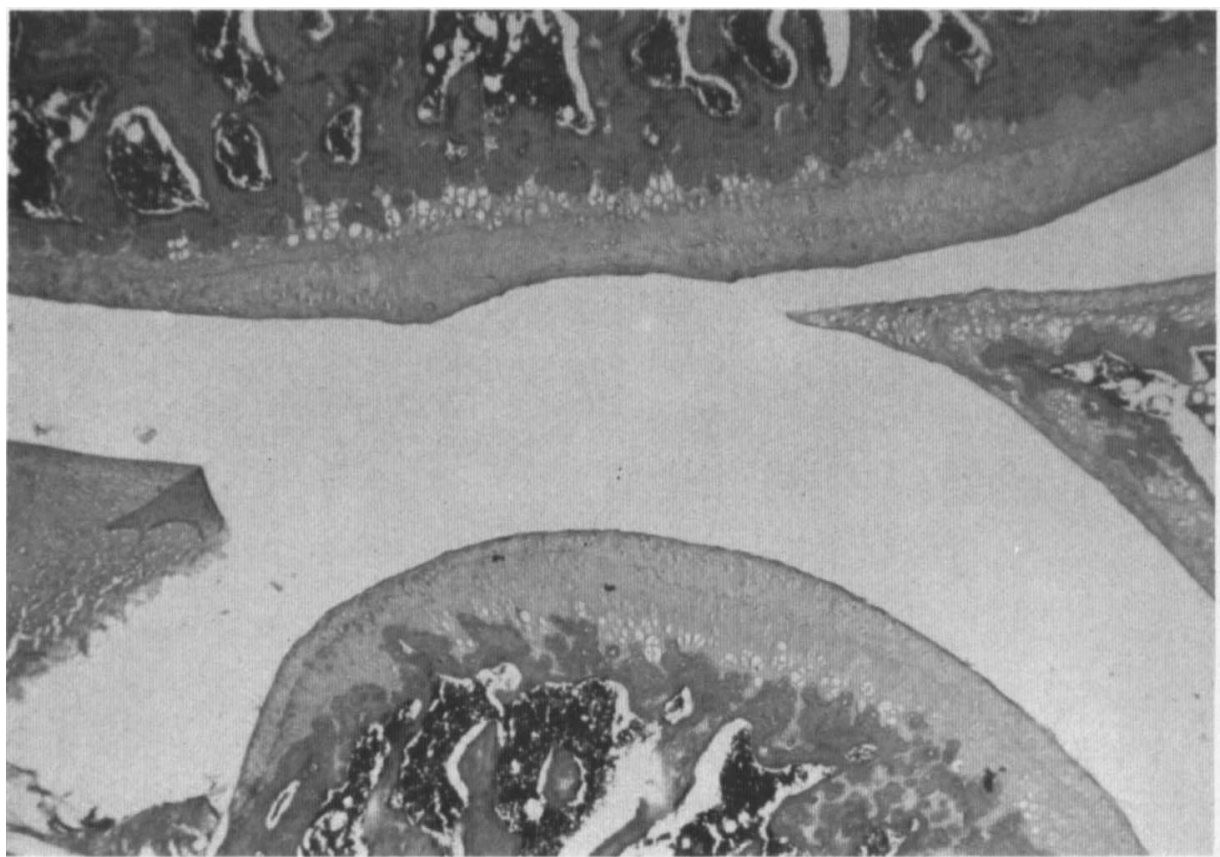

Fig. 3. Joint section from uninoculated control rat. The joint has a smooth delicate articular surface and normal joint space. Animals were maintained under the same conditions as the treated group. Controls receiving PBS or analytical grade rhamnose exhibited identical histological characteristics.

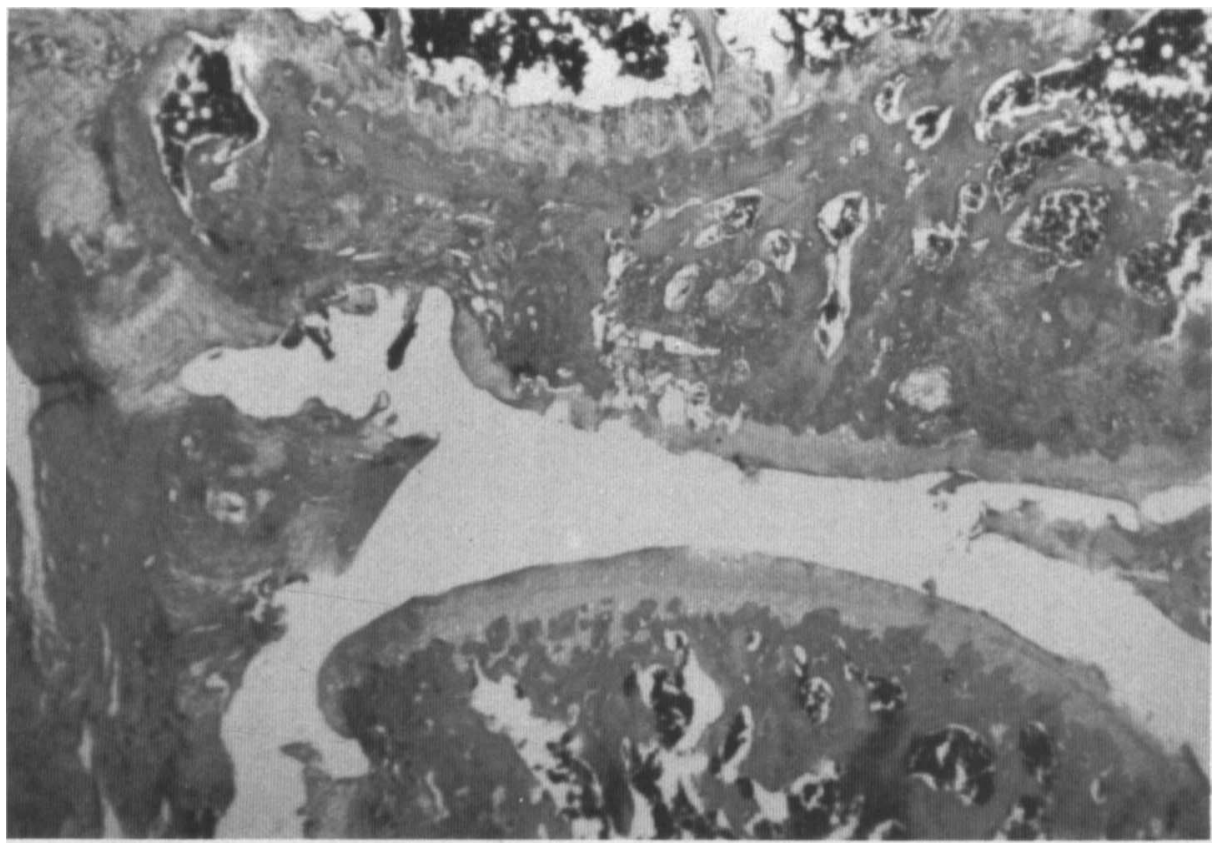

Fig. 4. Section of knee joint from rat 3 months after intra-articular injection with parent Group-A Streptococcus whole-cell sonicate (equivalent to rhamnose $60 \mu \mathrm{g} / \mathrm{g}$ body weight). Joint space has narrowed, osteofibrosis and pannus formation over the articular cartilage, plus breakage of the bone surface can be seen $(\mathrm{H} \& \mathrm{E}, \times 125)$. 


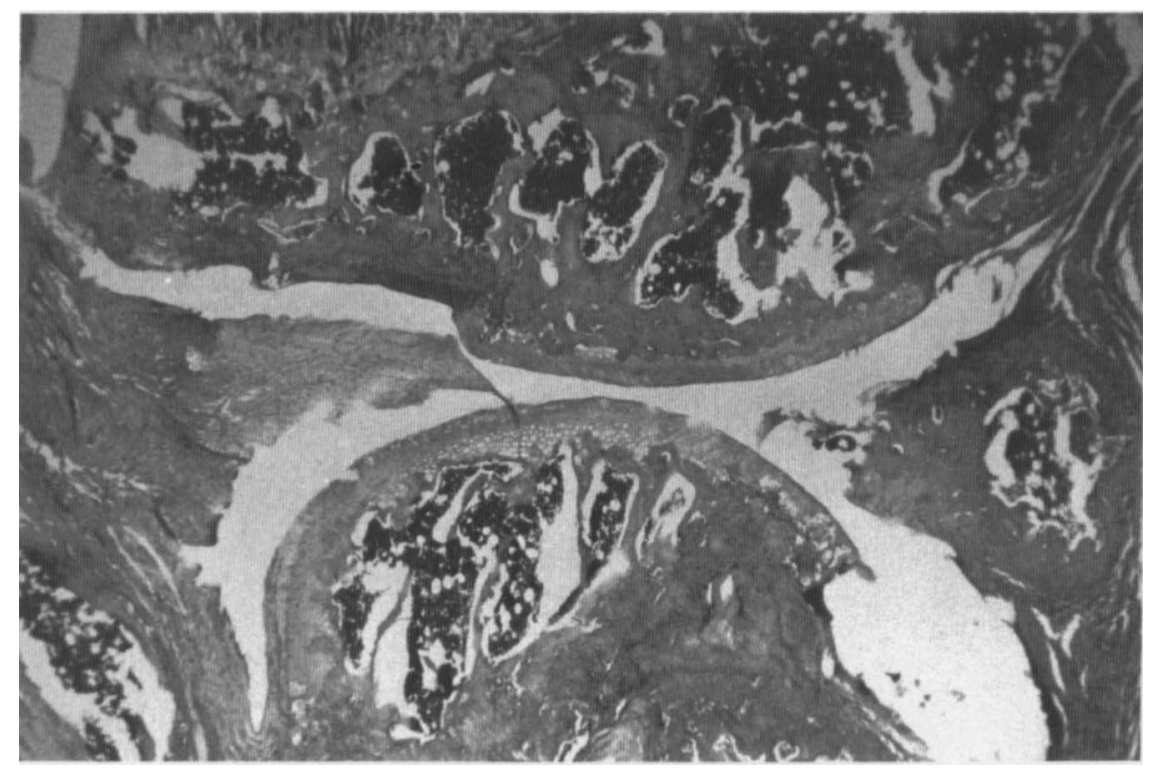

Fig. 5. Knee joint section from rat 3 months after injection of whole cell sonicate of non-haemolytic mutant (equivalent to rhamnose $60 \mu \mathrm{g} / \mathrm{g}$ body weight). Joint space has narrowed due to pannus extension over the articular cartilage and osteofibrosis is evident. (H $\& \mathrm{E}, \times 125)$.

walls (fig. 6) and correlated well with development of the chronic stage of arthritis observed in $\mathrm{H}$ \& $\mathrm{E}$ stained sections and by immunofluorescent staining.

\section{Discussion}

These results, as well as confirming findings of other investigators, establish for the first time a role for atypical non-haemolytic strains of $S$. pyogenes in the induction of experimental arthritis in Sprague-Dawley rats. This animal model has been widely used to study the arthropathic properties of $S$. pyogenes. The atypical strains induced a similar but less severe form of arthritis. It is not surprising to find that these atypical strains can induce arthritis if one assumes that the cell wall peptidoglycanpolysaccharide, or components of this complex, are responsible for its induction (Schwab et al., 1967; Cromartie et al., 1977; Clark et al., 1979; Dalldorf et al., 1980; Lambris et al., 1982; Chetty et al., 1983; Wilder et al., 1983; Esser et al., 1986). The non-haemolytic mutant used in this investigation has been described previously (Owens et al., 1978). It was non-haemolytic on surface and stab cultures and did not revert to $\beta$-haemolysis in the presence of reducing agents or in a GasPak atmosphere. The non-haemolytic mutant contained levels of hyaluronidase, DNAase, NADase, and streptolysin $O$ identical to those of the parent strain. The mutant was sensitive to bacitracin, pathogenic for mice and was identified by the Center for Disease Control in Atlanta, Georgia, as an M-type, T-type $12 S$. pyogenes, the same as the parent from which it was derived. Both the non-haemolytic mutant and the Lowry strain were deficient in streptolysin $S$ but retained their group characteristics and other cell-wall properties.

The serum concentration of immune complexes reached a peak about the same time that maximum immunofluorescence was observed and correlated well with development of the chronic stage of the disease. Detection of serum immune complexes with PEG is concentration dependent (Van der Giessen and The, 1986). It is not known whether the serum level of immune complexes in animals given streptococci in our study is dose dependent or not. Only those doses of antigen known to induce good arthritic response(s) were used in these experiments. The linear response noted in fig. 4 is a plot of detectable immune complex at specific times during the development of arthritis. Attempts to correlate immune-complex levels with antigen concentration were not made. We did note increased severity of the inflammatory response and chronic erosive stage of the disease with increased dose of antigen administered. A similar dose dependent relationship was observed by Eisenberg 

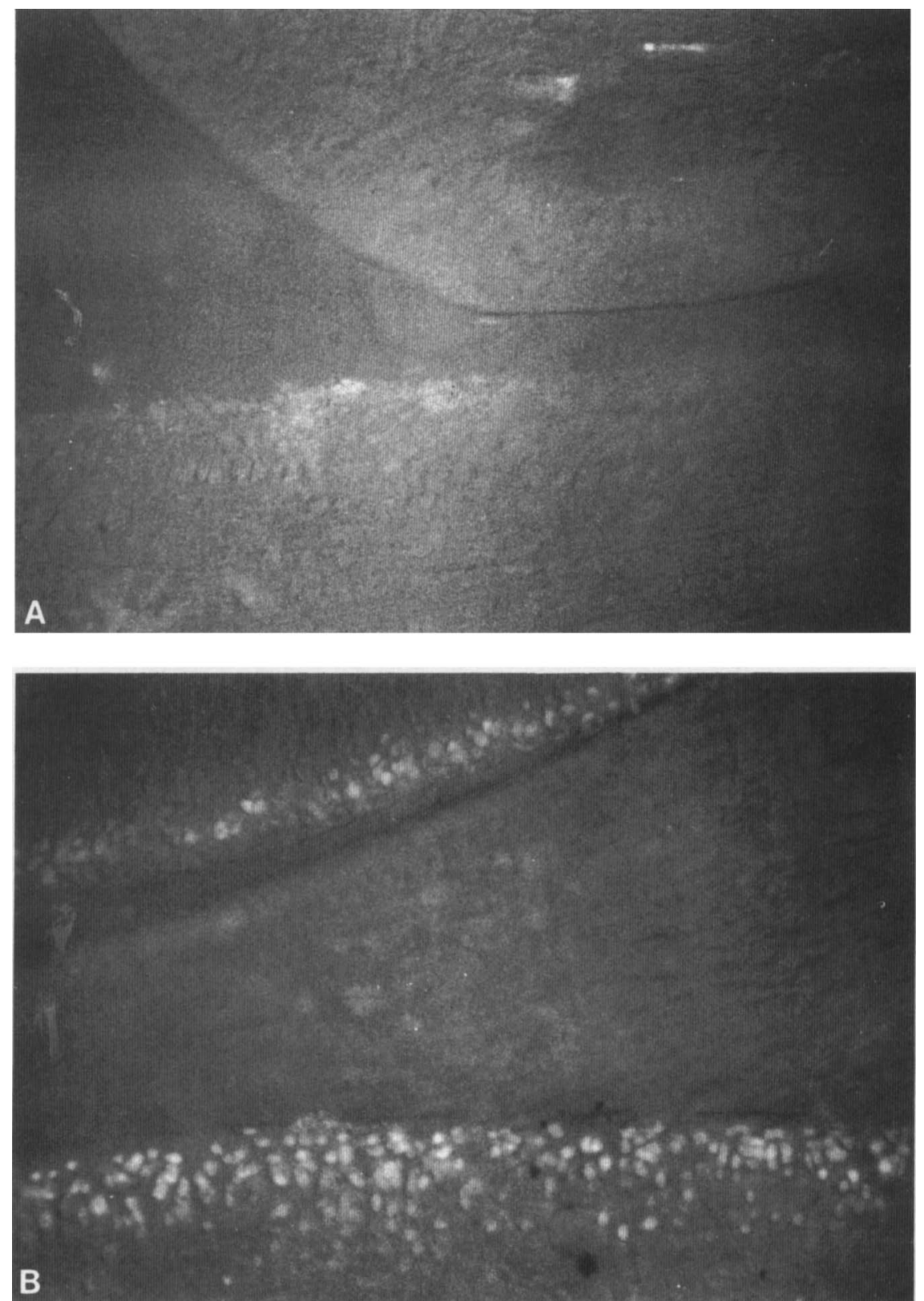

Fig. 6. Right knee joint from animals stained with fluorescent labelled anti-IgG 30,60 and 90 days after injection of mutant streptococcal cell walls (rhamnose $60 \mu \mathrm{g} / \mathrm{g}$ body weight). Fluorescence is visible in the synovial lining beginning $30 \mathrm{days}$ after injection, reaching a peak in 60 days, as well as in the joint cartilage after 90 days. A. Control. Animals received phosphate-buffered saline. Sections of knee joint were taken after 60 days and treated with fluorescein-conjugated rat anti-IgG. No fluorescence is detectable. B. Rats received cell-wall preparations of non-haemolytic mutant Streptococcus (rhamnose $60 \mu \mathrm{g} / \mathrm{g}$ body weight). Sections were taken from knee joints of arthritic rats 60 days after injection and stained with fluorescein labeled anti-IgG $(100 \times)$. Clear areas indicate fluorescence seen against a pale background. 


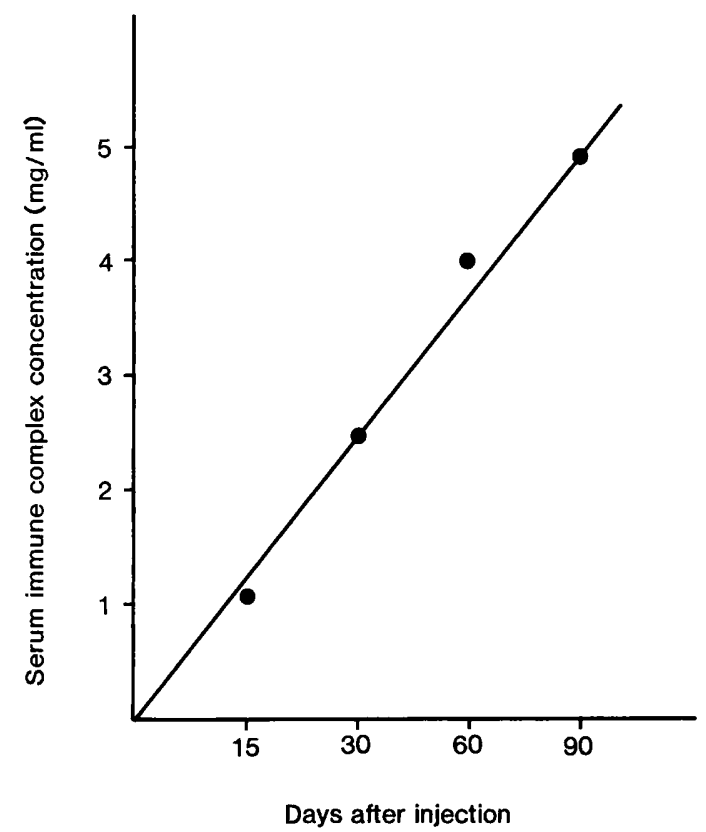

Fig. 7. Immune complex formation at various time intervals after injection of cell walls from the non-haemolytic mutant (equivalent to rhamnose $60 \mu \mathrm{g} / \mathrm{g}$ body weight). Serum was precipitated with $0.08 \mathrm{M}$ calcium carbonate and PEG $5 \%$ (in $0.1 \mathrm{M}$ borate buffer, $\mathrm{pH} 8.4$ ). The precipitate was removed by centrifugation, dissolved in $0 \cdot 1 \mathrm{M}$ sodium chloride and the optical density at $280 \mathrm{~nm}$ recorded.

et al. (1982) and Esser et al. (1986). If immune complexes are an integral part of this disease process, one would expect a dose dependent relationship between the antigen and amount of complex formed. The composition of these immune complexes is not known but could be similar to rheumatoid factors formed in man and other experimental animals.

Rheumatoid factors of the IgM and IgG classes

\section{REFERENCES}

Anderle S K, Greenblatt J J, Cromartie W J, Clark R, Schwab J H 1979 Modulation of the susceptibility of inbred and outbred rats to arthritis induced by cell walls of group A streptococci. Infection and Immunity 25 : 484-490.

Bannatyne R M, Robson A 1974 Bacteremia due to atypical streptococci belonging to Lancefield group A. Report of two cases. American Journal of Clinical Pathology 61 : 358 360 .

Carson D A, Bayer A S, Eisenberg R A, Lawerence S, Theofilopoulos A $1978 \mathrm{IgG}$ rheumatoid factor in subacute bacterial endocarditis: relationship to IgM rheumatoid factor and circulating immune complexes. Clinical and Experimental Immunology 31 : 100-103. have been shown to form immune complexes in serum or joint fluid by self association (Mannik, 1979) or reaction with native IgG (Carson et al., 1978). The complexes are capable of complement fixation, can activate phagocytic cells and may thereby elicit inflammatory erosive diseases in joints and extra-articular lesions (McDougal and McDuffie, 1985).

Activation of the alternate complement pathway has been suggested to be a significant factor in experimental arthritis induced by streptococcal cell-wall components (Greenblatt et al., 1980; Lambris et al., 1982). The detection of IgG in the joint tissues coupled with the presence of immune complexes in the serum during the chronic stages of experimental arthritis might also depend upon the same bacterial components. The presence of IgG in the synovial tissue, and later in cartilage, could be due to deposits of immune complexes of the IgG-IgG type. Our inability to detect IgM at any stage of the disease would appear to rule out IgG-IgM complexes.

It seems clear from this investigation that atypical strains of $S$. pyogenes can be pathogenic as measured by their ability to induce experimental arthritis in vitro. Involvement of atypical strains with naturally occurring disease processes is well documented (James and McFarland, 1971; Chapman, 1972; Bannatyne and Robson, 1974; Drapkin et al., 1976) and as such should be recognised as a group of medically important bacteria.

This investigation was supported in part by a grant from the American Heart Association-Louisiana, Inc., and by a seed grant from the University seed grant program (C.U.R.I.A.). The authors wish to thank Dr S. Sunni, University of Alabama in Birmingham, for his assistance with histological preparation and interpretation, to Dr Edna Mcleod, and Mr David Walker, Natchitoches Parish Hospital, Natchitoches, LA, for their assistance with $\mathrm{X}$-rays.

Chapman S S 1972 Unusual group A streptococci: colonial appearance and hemolysis. In: Wannamaker $\mathrm{L}$ W, Matsen J M (eds) Streptococci and streptococcal diseases : recognition, understanding and management. Academic Press, Inc., New York, pp 211-233.

Chetty C, Brown R R, Schwab J H 1983 Edema-producing activity of group A streptococcal polysaccharide and its possible role in the pathogenesis of cell wall-induced polyarthritis. Journal of Experimental Medicine 157: 10891101.

Clark R L, Cuttino J T, Anderle S K, Cromartie W J, Schwab J H 1979 Radiologic analysis of arthritis in rats after systemic injection of streptococcal cell walls. Arthritis and Rheumatism 22: 25-35.

Cromartie W J, Craddock J G, Schwab J H, Anderle S K, 
Yang C H 1977 Arthritis in rats after systemic injection of streptococcal cells or cell walls. Journal of Experimental Medicine 146: 1585-1602.

Dalldorf F G, Cromartie W J, Anderle S K, Clark R L, Schwab J H 1980 The relation of experimental arthritis to the distribution of streptococcal cell wall fragments. American Journal of Pathology 100: 383-402.

Dische Z, Shettles L B 1948 A specific color reaction of methylpentoses and a spectrophotometric micro-method for their determination. Journal of Biological Chemistry 175 : 595-603.

Drapkin M S, Karchmer A W, Moellering R C 1976 bacteremic infections due to clindamycin-resistant streptococci. Journal of the American Medical Association 236 : 263-265.

Eisenberg R, Fox A, Greenblatt J J, Anderle S K, Cromartie W J, Schwab J H 1982 Measurement of bacterial cell wall in tissues by solid-phase radioimmunoassay: Correlation of distribution and persistence with experimental arthritis in rats. Infection and Immunity 38: 127-135.

Esser R E, Anderle S K, Chetty C, Stimpson S A, Cromartie W J, Schwab J H 1986 Comparison of inflammatory reactions induced by intraarticular injection of bacterial cell wall polymers. American Journal of Pathology 122: 323334.

Greenblatt J J, Hunter N, Schwab J H 1980 Antibody response to streptococcal cell wall antigens associated with experimental arthritis in rats. Clinical and Experimental Immunology 42: 450-457.

Hunter N, Anderle S K, Brown R R, Dalldorf F G, Clark R L, Cromartie W J, Schwab J H 1980 Cell-mediated immune response during experimental arthritis induced in rats with streptococcal cell walls. Clinical and Experimental Immunology 42: 441-449.

James L, McFarland R B 1971 An epidemic of pharyngitis due to nonhemolytic group A streptococcus at Lowry Air Force Base. New England Journal of Medicine 284: 750-752.

Lambris J D, Allen J B, Schwab J H 1982 In vivo changes in complement induced with peptidoglycan-polysaccharide polymers from streptococcal cell walls. Infection and Immunity 35: 377-380.

Mannik M 1979 Rheumatoid factors. In: McCarty D J (ed) Arthritis and allied conditions. Lea and Febiger, Philadelphia, pp 504-512.

McDougal J S, McDuffie F C 1985 Immune complexes in man: detection and clinical significance. Advances in Clinical Chemistry 24: 1-60.

Owens W, Henley F, Barridge B D 1978 Hemolytic mutants of Group A Streptococcus pyogenes. Journal of Clinical Microbiology 7: 153-157.

Schwab J H, Cromartie W J, Ohanian S H, Craddock J 1967 Association of experimental chronic arthritis with the persistence of group A streptococcal cell walls in the articular tissue. Journal of Bacteriology 94 : 1728-1735.

Van der Giessen M, The T H 1986 Characterization of the soluble immune complexes that are detected by three different techniques. Clinical Immunology and Immunopathology 38: 244-255.

Wilder R L, Allen J B, Wahl L M, Calandara G B, Wahl S M 1983 The pathogenesis of group A streptococcal cell wallinduced polyarthritis in the rat: comparative studies in arthritis resistant and susceptible inbred rat strains. Arthritis and Rheumatism 26: 1442-1451. 